\title{
Pengaruh Bauran Pemasaran dan Kualitas Pelayanan Terhadap Loyalitas Anggota Pada Koperasi Syariah BMT di Rumbai-Pekanbaru
}

\author{
ARIZAL.N ${ }^{1}$; WITA DWIKA LISTIHANA ${ }^{2}$ \\ Dosen Tetap Universitas Lancang Kuning \\ Jln. Yos Sudarso Km 08 Rumbai Pekanbaru Telp. (0761) 52581 \\ E-mail : arizal.n@unilak.ac.id
}

\begin{abstract}
The purpose of this study is to know empirically the influence of Marketing Mix and Quality Peleyanan to Loyalty of members of Sharia Cooperative in Rumbai-Pekanbaru. The research method is descriptive method (survey) with quantitative research design, the data used is pimer and skunder.Poulasi data in this study is the total number of members of the cooperative sharia BMT in Rumbai-Pekanbaru. The number of samples in this study amounted to 90 people, where the determination of the number of samples was based on using the opinion of slovim. While the sampling technique is non random sampling technique with axidentalsampling method. The tool used in data analysis is by using WarpPLs. The results show that the marketing mix has a direct influence on loyalty of 0.30 means that the marketing mix will positively increase the loyalty of 0.30 . Quality of service also has a direct influence on loyalty of 0.42 means that the quality of service will positively increase loyalty of 0.42 .
\end{abstract}

Keywords: Marketing Mix, Service Quality and Loyalty

Undang-Undang No.10/1998 tentang perbankan dan UU No.23/1999 tentang Bank Indonesia telah secara nyata melegalkan dan mengukuhkan keberadaan bank syariah. Disamping itu munculnya secara khusus yaitu UU no $21 / 2008$ dan UU SBSN No 19/2008. Hal ini muncul adalah sangat mendukung dengan kondisi sebahagian besar bangsa Indonsia yng beragama Islam. Sehingga produk-produk syariah ini akan menjadi pilihan yang terbaik disaping produk kovensional yang telah dulu berkembang.Sedangkan koperasi menurut UU RI No.25 Tahun 1992 adalah badan usaha yang beranggotakan orangseorang atau badan hokum Koperasi dengan melandaskan kegiatannya berdasarkan prinsip Koperasi sekaligus sebagai gerakan ekonomi rakyat yang berdasar atas asas kekeluargaan.

Sedangkan pengertian Koperasi BMT (Baitul Maal wat Tamwil) dari Balai Usaha Mandiri Terpadu adalah lembaga keuangan mikro yang dioperasikan dengan prinsip bagi hasil, menumbuh kembangkan bisnis usaha mikro dan kecil, dalam rangka mengangkat derajat dan martabat serta membela kepentingan kaum fakir miskin.

Koporasi syariah atau Baitul Mal Wa Tamwil (BMT) adalah terdiri dari dua istilah, yaitu baitul mal dan baitut tamwil. Baitul maal lebih mengarah pada usaha-usaha pengumpulan dan penyaluran dana yang non profit, seperti zakat, infak dan shodaqoh. Sedangkan baitut tamwil sebagai usaha pengumpulan dan dan penyaluran dana komersial (Djazuli:2002).

BMT termasuk dalam kategori usaha mikro kecil dan menengah (UMKM). Dimana menurut UU RI No. 20 tahun 2018 tentang Usaha Kecil dan Menengah meyatakan bahwa Usaha Mikro, Kecil, dan Menengah merupakan kegiatan usaha yang mampu memperluas lapangan kerja dan memberikan pelayanan ekonomi secara luas kepada masyarakat, dan dapat berperan dalam proses pemerataan dan peningkatan pendapatan masyarakat, mendorong pertumbuhan ekonomi, dan berperan dalam mewujudkan stabilitas nasional. Selain itu, Usaha Mikro, Kecil, dan 
Menengah adalah salah satu pilar utama ekonomi nasional yang harus memperoleh kesempatan utama, dukungan, perlindungan dan pengembangan seluas-luasnya sebagai wujud keberpihakan yang tegas kepada kelompok usaha ekonomi rakyat, tanpa mengabaikan peranan Usaha Besar dan Badan Usaha Milik Negara.

Adanya perkembangan dalam dunia bisnis yang sangat pesat juga menjadikan tantangan dalam bisnis sektor jasa keuangan seperti BMT menjadi semakin besar, persaingan yang semakin ketat, dan penggunaan teknologi yang semakin canggih, serta konsumen yang semakin variatif. Kondisi ini secara tidak langsung menuntut BMT untuk dapat semakin mengembangkan bauran pemasaran dan kualitas pelayanannya sehingga dapat mendatangkan loyalitas bagi anggotanya.

Koperasi syariah BMT harus dapat mnciptakan Loyalitas bagi angotanya, melalui berbagai program bauran pemasaran dan juga memberikan kualitas pelayanan yang yang baik melalui berbagai dimensi dalam pelayanan tersebut. Diamping itu pihak koperasi Syariah juga harus mempunyai hubungan baik kapada anggotanya.

Sementara itu Tjiptono (2007:18) bauran pemasaran jasa adalah terdiri dari 7P's, yaitu: product (produk), price (harga), place (lokasi), promotion (promosi), people or participant (penyedia jasa/orang), process (proses jasa), dan physical evidence (bukti fisik).

Tingkat loyalitas pelanggan disamping ditentukan oleh kebijaksanaan bauran pemasaran, juga ditentukan oleh tingkat kualitas pelayanan yang diberikan. Tingkat kualitas pelayanan yang baik akan dapat member rasa puas dan akan mendatangkan loyalitas.

Menurut Tjiptono, dkk (2008: 70) kualitas layanan mencerminkan perbandingan antara tingkat layanan yang disampaikan perusahaan dibandingkan ekspektasi pelanggan. Kualitas layanan diwujdkan melalui pemenuhan kebutuhan dan keinginan pelanggan serta ketepatan penyampaiannya dengan mengimbangi atau melebihi harapan pelanggan.

Kotler dalam Alma (2005:284285) mengungkapkan ada lima faktor dominan atau penentu kualitas jasa disingkat dengan TERRA yaitu :

a. Tangible (berwujud), yaitu berupa penampilan fasilitas fisik, peralatan dan berbagai materi komunikasi yang baik, menarik, terawat lancar, dsb.

b. Emphaty yaitu kesediaan karyawan dan pengusaha untuk lebih peduli memberikan perhatian secara pribadi kepada langganannya.

c. Responsiveness (cepat tanggap) yaitu kemauan dari karyawan dan pengusaha untuk membantu pelanggan dan memberikan ajsa dengan cepat serta mendengar dan emngatasi keluhan/ complaint dari konsumen.

d. Reliability (keandalan) yaitu kemampuan untuk memberikan jasa sesuai dengan yang dijanjikan, terercaya dan akurat dan konsisten.

e. Assurance (kepastian), yaitu berupa kemampuan karyawan untuk menimbulkan keyakinan dan kepercayaan terhadap janji yang telah dikemukakan kepada konsumen.

Menurut Hurriyati (2008,): "Bauran pemasaran jasa adalah elemenelemen organisasi perusahaan yang dapat dikontrol oleh perusahaan dalam melakukan komunikasi dengan konsumen dan akan dipakai untuk memuaskan konsumen

Menurut Zeithaml dan Bitner yang dikutip dalam Hurriyati (2008), mengemukakan konsep bauran pemasaran tradisional yang terdiri dari $4 \mathrm{P}$, yaitu product, price, place, dan promotion.Sementara itu, untuk pemasaran jasa perlu bauran pemasaran yang diperluas (expanded marketing mix for services) dengan penambahan unsur non-tradisional marketing mix, yaitu people (orang), physical evidence (fasilitas fisik), dan proses, sehingga menjadi tujuh unsur (7P).

p.ISSN: 2407-800X e.ISSN: 2541-4356 
Sementara itu Tjiptono (2007:18) bauran pemasaran jasa adalah terdiri dari 7P's, yaitu: product (produk), price (harga), place (lokasi), promotion (promosi), people or participant (penyedia jasa/orang), process (proses jasa), dan physical evidence (bukti fisik).

Keberhasilan jasa dalam mencapai tujuannya adalah sangat tergantung kepada bauran pemasaran dan kualitas pelayan yang diberikannya kepada setiap pelanggan. Dimana kualitas layanan mencerminkan perbandingan antara tingkat layanan yang disampaikan perusahaan dibandingkan ekspektasi pelanggan. Kualitas layanan diwuujdkan melalui pemenuhan kebutuhan dan keinginan pelanggan serta ketepatan penyampaiannya dengan mengimbangi atau melampaui harapan pelanggan.(Tjiptono, dkk 2008: 70). Kualitas memberikan suatu dorongan kepada pelanggan untuk menjalin ikatan yang kuat dengan perusahaan. (Parasuraman dalam sangadji dan sopiah;2013;100). Kualitas jasa sebagai tingkat ke unggulan yang diharapkan dan pengendalian atas tingkat ke unggulan tersebut untuk memenuhi keiginan pelanggan (sangadji \& sopiah;2013;99100).

Kotler dalam Alma (2005: 284-285) mengungkapkan ada lima faktor dominan atau penentu kualitas jasa disingkat dengan TERRA yaitu :

a. Tangible (berwujud), yaitu berupa penampilan fasilitas fisik, peralatan dan berbagai materi komunikasi yang baik, menarik, terawat lancar, dsb.

b. Emphaty yaitu kesediaan karyawan dan pengusaha untuk lebih peduli memberikan perhatian secara pribadi kepada langganannya.

c. Responsiveness (cepat tanggap) yaitu kemauan dari karyawan dan pengusaha untuk membantu pelanggan dan memberikan ajsa dengan cepat serta mendengar dan emngatasi keluhan/ complaint dari konsumen. d. Reliability (kehandalan) yaitu kemampuan untuk memberikan jasa sesuai dengan yang dijanjikan, terercaya dan akurat dan konsisten.

e. Assurance (kepastian), yaitu berupa kemampuan karyawan untuk menimbulkan keyakinan dan kepercayaan terhadap janji yang telah dikemukakan kepada konsumen.

Studi mengenai SERQUAL oleh parasuraman ( 1988) dalam Lupiyoadi;2006;182 menyimpulkan bahwa terdapat lima dimensi kualitas pelayanan yang disebut dengan SERVQUAL. Kelima dimensi kualitas pelayanan tersebut adalah sebagai berikut:

1. Berwujud (Tangible) yaitu kemampuan suatu perusahaan dalam menunjukkan eksistensinya kepada pihak eksternal. Penampilan dan kemampuan sarana dan prasarana fisik perusahaan yang dapat diandalkan keadaan lingkungan sekitarnya merupakan bukti nyata dari pelayanan yang diberikan oleh pemberi jasa. Hal ini meliputi fasilitas fisik (contoh : gedung, gudang, dan lain- lain), perlengkapan dan peralatan yang dipergunakan (teknologi) serta penampilan pegawainya.

2. Keandalan (Reliability) yaitu kemampuan perusahaan untuk memberikan pelayanan sesuai dengan yang dijanjikan secara akurat dan terpercaya. Kinerja harus sesuai dengan harapan pelanggan yang berarti ketepatan waktu, pelayanan yang sama untuk semua pelanggan tanpa kesalahan, sikap yang simpatik, dan dengan akurasi yang tinggi.

3. Ketanggapan (Responsiveness) yaitu suatu kebijakan kemauan untuk membantu dan memberikan pelayanan yang cepat (responsif) dan tepat kepada pelanggan dengan penyampaian informasi

p.ISSN: 2407-800X e.ISSN: 2541-4356 
yang jelas. Membiarkan konsumen menunggu persepsi yang negatif dalam kualitas pelayanan.

4. Jaminan dan kepastian (Assurance) yaitu pengetahuan, kesopansantunan, dan kemampuan para pegawai persahaan untu menumbuhkan rasa percaya para pelanggan kepada perusahaan. Hal ini meliputi beberapa komponen antara lain komunikasi ( communication ), kredibilitas ( credibility), keamanan ( security), kompetensi ( competence) dan sopan santun ( courtesy).

5. Empati (emphaty) yaitu memberikan perhatian yang tulus dan bersifat individual atau pribadi yang diberikan kepada para pelanggan dengan berupaya memahami keinginan konsumen. Dimana suatu perusahaan diharapkan memiliki pengertian dan pengetahuan tentang pelanggan, memahami kebutuhan pelanggan secara spesifik, serta memiliki waktu pengoperasian yang nyaman bagi pelanggan.

Goetsch \& Davis (2010) dalam Tjiptono (2016:115), mendefinisikan kualitas sebagai kondisi dinamis yang berhubungan dengan produk, jasa, sumber daya manusia, proses dan lingkungan yang memenuhi atau melebihi harapan.

Griffin $(2003$; 223) mengemukakan keuntungan-keuntungan yang akan diperoleh perusahaan apabila memiliki pelanggan yang loyal antara lain:

a. Mengurangi biaya pemasaran (karena biaya untuk menarik pelanggan baru lebih mahal).

b. Mengurangi biaya transaksi (seperti biaya negosiasi kontrak, pemrosesan pesanan, dll).

c. Mengurangi biaya turn over pelanggan (karena pergantian pelanggan yang lebih sedikit).

d. Meningkatkan penjualan silang yang akan memperbesar pangsa pasar perusahaan. e. Word of mouth yang lebih positif dengan asumsi bahwa pelanggan yang loyal juga berarti mereka yang merasa puas.

Selanjutnya

Griffin mengemukakan tentang cirri-ciri pelanggan yang loyal yaitu; a. Rutin menggunakan jenis jasa tertentu dari suatu perusahaan. b. Menggunakan jasa lainnya dari perusahaan tersebut. c. Kemauan untuk merekomendasikan jasa perusahaan kepada pihak/orang lain, dan d. Keberanian untuk menolak tawaran pesaing.

Hasil peneliian Putra, dkk, dengan judul Pengaruh bauran pemasaran jasa terhadap kepuasan dan loyalitas nasabah PT. Pegadaian (persero) cabang Mengwi, Badung, Bali. Menunjukkan bahwa hasil penelitian terdapat pengaruh yang segnifikan dari bauran pemasaran jasa yang terdiri dari produk, harga, promosi, tempat, orang, bukti fisik, dan proses secara simultan dan parsial terhadap kepuasan dan juga terhadap loyalitas.

Dari hasi penelitian Tuti hastuti dkk 2014, dengan judul Kualitas Pelayanan, Kepuasan, Dan Loyalitas Nasabah: Aplikasi Servqual Model Pada Lembaga Keuangan Mikro Syariah Kota Malang. Pada penelitian ini sampel yang digunakan adalah 112 responden selaku nasabah lembaga keuangan Mikro Syariah (LKMS) Kota Malang. Hasil penelitian: Kualitas pelayanan berpengaruh signifikan terhadap kepuasan nasabah, sedangkan dimensi tangibles dan emphaty tidak berpengaruh terhadap kepuasan. Diamping itu hasil lain adalah kualitas layanan berpengaruh siginifikan terhadap loyalitas nasabah melalui kepuasan nasabah.

Hasil penelitian yang berjudul Pengaruh Bauran Pemasaran Jasa terhadap Loyalitas Anggota Pada KJKS BMT Bina Ummar Sejahera Lasem Cabang Kudus oleh awijayanti dan Sumekar. (2009;30), menunjukkan bahwa secra simultan Bauran pemasaran 
mempunyai pengaruh yag significant terhadp loyalitas anggota koperasi BMT.

Selanjutnya penelitian yang berjudul Pengaruh Kualitas Pelayanan Terhadap Kepuasan dan Loyalitas Nasabah PT BPR HOKI di Kabupaten Tabanan oleh Dewi dkk. (2014 :257). Hasil analisis statistik menunjukkan bahwa kualitas pelayanan, kepuasan nasabah, dan loyalitas memiliki hubungan yang positif dan signifikan.

\section{METODE}

Jenis penelitian ini adalah metode deskriptif (survey) dengan desain penelitian kualitatif yaitu untuk mengetahui pelaksanaan dari bauran pemasaran, kualitas pelayan dan loyalitas. Dissamping itu disain kuantitatif, yaitu penelitian tidak hanya memberikan gambaran mengenai fenomena tetapi juga menerangkan, menguji hipotesis dan mendapatkan makna dari fakta yang ada.

Jenis dan sumber data yang digunakan dalam penelitian ini adalaah data primer dan data skunder. Populasi yang digunakan dalam penelitian ini adalah seluruh anggota koperasi syariah BMT yang ada di Rumbai-Pekanbaru, yatu BMT Ittihad dan BMT Mitra Arta. Jumlah populasi adalah 6.840 orang pada tahun 2015. Karena banyaknya populasi maka dalam penelitian ini diambil sampel. Jumlah sampel dalam penelitian ini adalah 99 oraang, dimana ukuran sampel menggunakan pendapat slovin, dengan tingkat error $10 \%$.

Teknik pengambilan sampel. dalam penelitian ini dilakukan dengan menggunakan teknik non random sampling dengan cara metode purposive sampling. Metode purposive sampling adalah pengambilan sampel berdasarkan pertimbangan subjektif peneliti, dimana syarat dibuat sebagai kriteria yang harus dipenuhi oleh sampel (Algifari).

Teknik analisis data yang digunakan pada penelitian ini adalah dengan menggunakan metode analisi Kuesioner yang digunakan untuk mengumpulkan data dari variabel-variabel yang diteliti menggunakan skala Likert untuk setiap jawaban diberi skor nilai yang digunakan adalah kriteria sangat setuju (5), sampai dengan sangat tidak setuju (1).Pengujian pengaruh variabel yang dihipotesiskan dalam penelitian ini menggunakan model persamaan struktural (Warp.PLs.5).

\section{HASIL}

Analisis data penelitian dilakukan melalui dua tahap, yaitu tahap pertama adalah melakukan evaluasi terhadap model pengukuran (outer model) dengan cara menguji validitas dan reliabilitas untuk setiap variabel penelitian. Kemudian tahap kedua adalah melakukan evaluasi terhadap model struktrual (inner model). Evaluasi terhadap outer model dalam penelitian adalah untuk melihat apakah instrumen yang digunakan untuk variable bauran pemasaran dan Kualitas pelayanan serta loyalitas memiliki tingkat ketepatan dan akurasi serta konsistensi yang baik (Hartono, 2011; Abdillah dan Hartono, 2015). Evaluasi terhadap outer model dilakukan melalui uji validitas konvergen, validitas diskriminan, dan reliabilitas.

Berikut disajikan outer model validitas seperti pada tabel berikut ini;

Tabel 1. Outer Mofel Validitas

\begin{tabular}{|c|c|c|c|c|}
\hline & Indicator & $\begin{array}{l}\text { Loading } \\
\text { factor }\end{array}$ & AVE & KRITERIA \\
\hline \multirow{7}{*}{$\begin{array}{l}\text { Bauran } \\
\text { Pemasaran }\end{array}$} & BP 01 & 0.484 & \multirow{7}{*}{0.346} & \multirow{7}{*}{ VALID } \\
\hline & BP 02 & 0.693 & & \\
\hline & BP 03 & 0,43 & & \\
\hline & BP 04 & 0,624 & & \\
\hline & BP 05 & 0.168 & & \\
\hline & BP 06 & 0.797 & & \\
\hline & BP 07 & 0.688 & & \\
\hline \multirow{5}{*}{$\begin{array}{l}\text { Kepuasan } \\
\text { Pelanggan }\end{array}$} & KP 01 & 0.799 & \multirow{5}{*}{0.695} & \multirow{5}{*}{ VALID } \\
\hline & KP 02 & 0.896 & & \\
\hline & KP 03 & 0.917 & & \\
\hline & KP 04 & 0.839 & & \\
\hline & KP 05 & 0.69 & & \\
\hline \multirow[t]{3}{*}{ Loyalitas } & L1 & 0.831 & \multirow{3}{*}{0747} & \multirow{3}{*}{ VALID } \\
\hline & L2 & 0.919 & & \\
\hline & L3 & 0.841 & & \\
\hline
\end{tabular}

Sumber : Data Olahan.

Pada tabel tersebut diatas dapat diketahui bahwa hampir semua variable dan indikator adalah valid yang berarti bahwa semua instumen yang digunakan pada penelitian ini adalah benar dan terpecaya, baik dari bauran pemasaran dan indikatornya, kepercayaan dan indikatornya dan loyalitasa dan indikatornya. Sedangkan untuk indikator B05 yaitu mengenai

$$
\text { p.ISSN: 2407-800X e.ISSN: 2541-4356 }
$$


prosedur dalam bauran pemasaran hasilnya adalah tidak valid.

Sedangkan untuk uji realibility yaitu bagaimana tingkat konsistensi dari alat pengukurn yang digunakan dalam penelitian ini dapat dilihat dari tabel berikut;

Tabel 2 Outer Mofel Realibility

\begin{tabular}{|l|l|l|l|}
\hline & $\begin{array}{l}\text { Composite } \\
\text { reliability }\end{array}$ & $\begin{array}{l}\text { Cronbach's } \\
\text { alpha }\end{array}$ & KRITERIA \\
\hline $\begin{array}{l}\text { Bauran } \\
\text { Pemasaran }\end{array}$ & 0.767 & 0.649 & Reliabel \\
\hline $\begin{array}{l}\text { Kualitas } \\
\text { Pelayanan }\end{array}$ & 0,919 & 0.887 & Reliabel \\
\hline Loyalitas & 0,898 & 0,830 & Reliabel \\
\hline
\end{tabular}

Sumber; Data Olahan.

Dari tabel diatas dapat diihat bahwa semua intrumen penelitian yaitu bauran pemasaran, kualitas pelayanan dan loyalitas adalah reliable. Ini berarti bahwa alat ukur yang digunakan adalah dapat dijaga konsistensinya.

Gambar.1

Model Struktural Penelitian

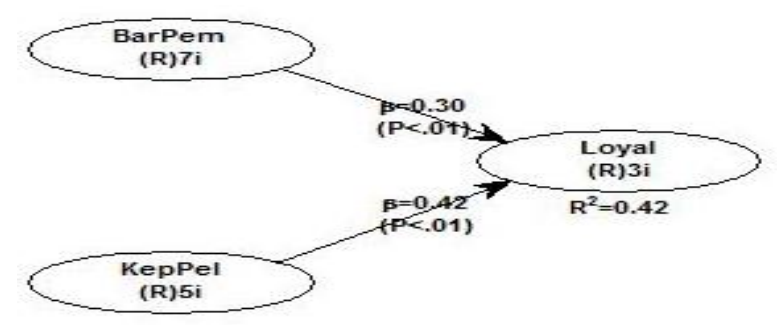

Dari struktural model diatas dapat diketahui bagaimana pengaruh dari variabel penelitian bauran pemasaran dan kualitas pelayanan terhadap loyalitas. Bauran pemasaran mempunyai pengaruh langsung terhadap loyalitas sebesar 0,30 dengan signifikan nilai $\mathrm{p}<0,01$. Hal ini berarti bahwa apabila bauran pemasaran ditingkatkan maka juga akan dapat meningkatkan tingkat loyalitas secara positif.

Hal ini mencerminkan bahwa Koperasi Syariah BMT harus dapat meningkatkan dari kualitas bauran pemasarannya, sehingga akan dapat meningkatkan loyalitas anggota koperasi tersebut. Demikian juga kualitas pelayanan mempunyai pengaruh langsung terhadap loyalitas sebesar 0,42 terhadap loyalitas dengan tingkat signifikan $p<0,01$. Ini berarti bahwa dengan peningkatan dalam kualittas pelayanan akan secara positif juga akan dapat menigkatkan loyalitas dari anggota Koperasi Syariah BMT di RumbaiPekanbaru.

Hasil pengukuran koefisien determinasi adalah sebesar 0,42 ini menunjukkan bahwa tingkat loyalitas vaiansinya dapat dijelaskan oleh bauran permasaran dan tingkat kualitas pelayan sebesar 0,42 , sedangkan sisanya 0,58 itu akan dijelaskan oleh faktor lainnya.

\section{PEMBAHASAN}

Keberhasilan jasa dalam mencapai tujuannya adalah sangat tergantung kepada bauran pemasran dan kualitas pelayanan yang diberikannya kepada setiap pelanggan. Bauran pemasaran dan Kualitas pelayanan jasa yang diberikan hendaknya sama dengan apa yang diharapkan oleh konsumen. Bauran pemasaran jasa adalah berbagai bauran dalam jasa yang digunakan dalam rangka untuk mencapai tujuan perusahaan jasa. Bauran ini meliputi produk, harga/tariff, tempat, promosi, process, kariyawan dan custumer service.

Sedangkan Goetsch \& Davis (2010) dalam Tjiptono (2016:115), mendefinisikan kualitas sebagai kondisi dinamis yang berhubungan dengan produk, jasa, sumber daya manusia, proses dan lingkungan yang memenuhi atau melebihi harapan.

Kotler dalam Alma (2005: 284-285) mengungkapkan ada lima faktor dominan atau penentu kualitas jasa disingkat dengan TERRA yaitu :

a. Tangible (berwujud), yaitu berupa penampilan fasilitas fisik, peralatan dan berbagai materi komunikasi yang baik, menarik, terawat lancar, dsb.

b. Emphaty yaitu kesediaan karyawan dan pengusaha untuk lebih peduli memberikan perhatian secara pribadi kepada langganannya.

c. Responsiveness (cepat tanggap) yaitu kemauan dari karyawan dan pengusaha untuk membantu pelanggan dan memberikan ajsa dengan cepat serta

p.ISSN: $2407-800 X \quad$ e.ISSN: 2541-4356 
mendengar dan mengatasi keluhan/ complain dari konsumen.

d. Reliability (kehandalan) yaitu kemampuan untuk memberikan jasa sesuai dengan yang dijanjikan, terercaya, akurat dan konsisten.

e. Assurance (kepastian), yaitu berupa kemampuan karyawan untuk menimbulkan keyakinan dan kepercayaan terhadap janji yang telah dikemukakan kepada konsumen.

Dari hasil penelitian Pengaruh bauran pemasaran terhadap loyalitas adalah sebesar 0,30 yang berarti bahwa loyalitas dipengaruhi sebesar $30 \%$ oleh bauran pemasaran dan juga kualitas pelayaan mempunyai pengaru sebesar 0,42 yang berarti bahwa loyalitas dipengaruhi oleh kualitas pelaayanan sebesar $0,42 \%$.

Hasil penelitian ini sejalan dengan hasil penelitian Tuti hastuti dkk 2014, dengan judul Kualitas Pelayanan, Kepuasan, Dan Loyalitas Nasabah: Aplikasi Servqual Model Pada Lembaga Keuangan Mikro Syariah Kota Malang. Hasil penelitian: Kualitas pelayanan berpengaruh signifikan terhadap kepuasan dan loyalitas nasabah. Hasil peneliian Putra, dkk, dengan judul Pengaruh bauran pemasaran jasa terhadap kepuasan dan loyalitas nasabah PT. Pegadaian (persero) cabang Mengwi, Badung, Bali. Menunjukkan bahwa hasil penelitian terdapat pengaruh yang segnifikan dari bauran pemasaran jasa yang terdiri dari produk, harga, promosi, tempat, orang, bukti fisik, dan proses secara simultan dan parsial terhadap kepuasan dan juga terhadap loyalitas.

Hasil penelitian awijayanti dan Sumekar. (2009;30), yang berjudul Pengaruh Bauran Pemasaran Jasa terhadap Loyalitas Anggota Pada KJKS BMT Bina Ummar Sejahera Lasem Cabang Kudus juga menunjukkan bahwa secra simultan Bauran pemasaran mempunyai pengaruh yag significant terhadp loyalitas anggota koperasi BMT.

Selanjutnya penelitian yang berjudul Pengaruh Kualitas Pelayanan Terhadap Kepuasan dan Loyalitas Nasabah PT BPR
HOKI di Kabupaten Tabanan oleh Dewi dkk. (2014 :257). Hasil analisis statistik menunjukkan bahwa kualitas pelayanan, kepuasan nasabah, dan loyalitas memiliki hubungan yang positif dan signifikan

\section{SIMPULAN}

Dari hasil penelitian tersebut diatas maka dapat diambil beberapa kesimpulan bahwa bauran pemasaran mempunyai pengaruh langsung terhadap loyalitas sebesar 0,30 berarti bahwa bauran pemasaran secara positif akan dapat meningkatkan loyalitas sebesar 0,30. Kualitas pelayanan mempunyai pengaruh langsung terhadap loyalitas sebesar 0,42 berarti bahwa kualiats pelayanan secara positif akan dapat meningkatkan loyalitas sebesar 0,42. Hasil pengukuran koefisien determinasi adalah sebesar 0,42 ini menunjukkan bahwa tingkat loyalitas vaiansinya dapat dijelaskan oleh bauran permasaran dan tingkat kualitas pelayan sebesar 0,42 , sedangkan sisanya 0,58 itu akan dijelaskan oleh faktor lainnya.

Dari hasil penelitian tersebut juga dapat disarankan hal-hal sebagai berikut: Sebaiknya Koperasi Syariah BMT dapat meningkatkan pelaksanaan bauran pemasaran agar terdapatnya peningkatan dalam loyalitas anggota BMT. Sebaiknya Koperasi Syariah BMT dapat meningkatkan tingkat kualitas pelayanan kepada anggota, sehingga akan dapat meningkatnya loyalitas anggota.

\section{DAFTAR RUJUKAN}

Alma, Buchari, H. Dr. Prof. Manajemen Pemasaran dan Pemasaran Jasa, Penerbit : Alfabeta, Bandung.

Gultom, dkk 2014 Pengaruh Bauran Pemasaran Jasa Dan Kualitas Pelayanan Terhadap Kepuasan Mahasiswa Program studi manajemen fakultas ekonomi universitas muhammadiayah sumatera utara (Jurnal Manajemen $\&$ Bisnis) volume 14 nomor 01

p.ISSN: $2407-800 X \quad$ e.ISSN: $2541-4356$ 
Griffin, Jill, 2005; Costumer Loyalty menumbuhkan \& Mempertahankan Kesetiaan Pelanggan, Penerbit Erlangga Jakarta.

Kotler, Philip, 2000, Manajemen Pemasaran, Jilid 1, Alih Bahasa Drs. Jaka Wasana, MSM,Penerbit : Erlangga, Jakarta.

tta Mamang Sangadji, Dr. M.Si., Dr. Sopiah, MM., M.Pd., 2013, Perilaku Konsumen, Pendekatan Praktis Disertai Himpunan Jurnal Penelitian, Andy, Yogyakarta.

Rambat Lupiyoadi. 2008. Manajemen Pemasaran Jasa : Teori dan Praktek.Jakarta: PT Salemba Empat.

dan A. Hamdani. 2006. Manajemen Pemasaran Jasa. Jakarta:Salemba Empat.

Rangkuti, Freddy 2002. Measuring coustemer Satifaction.: Gaining Customer

Sugiyono. 2009. Metode Penelitian Bisnis. Bandung: CV. Alfabeta.

Sholihin Mahfud dan Ratmono Dwi, 2013, Analisis SEM-PLS dengan WarpPLS 3.0, Penerbit Andi Yogyakarta.

Tjiptono, Fandi dan Gregorius Candra, 2005. Service, Quality, and Satisfaction. Andi Offset: Yogyakarta.

, 2011, Service, Quality, and Satisfaction. Andi Offset: Yogyakarta

Tjiptono, Fandy. 2004, Manajemen Jasa, Andi, Yogyakarta.

Ade letrio Putra, dkk Pengaruh bauran pemasaran jasa terhadap kepuasan dan loyalitas nasabah PT. Pegadaian (persero) cabang

Jurnal Daya Saing
Mengwi, Badung, Bali (Jurnal Fakultas Ekonomi Udayana)

Tuti hastuti dkk 2014 Kualitas Pelayanan, Kepuasan, Dan Loyalitas Nasabah: Aplikasi Servqual Model Pada Lembaga Keuangan Mikro Syariah Kota Malang (jurnal manajemen dan akutansi) vol 3 nomor 3 .

Wahjono, Sentot Imam, 2010, Bisnis Modern, Graha Ilmu, Yogyakarta 